\title{
Geolocator study reveals east African migration route of Central European Common Terns
}

\author{
Jelena Kralj ${ }^{*} \mathbb{D}$, Miloš Martinović ${ }^{1}$, Luka Jurinović ${ }^{2}$, Péter Szinai ${ }^{3}$, Szandra Sütő ${ }^{4}$ and Bálint Preiszner ${ }^{5}$
}

\begin{abstract}
Background: The majority of European Common Terns (Sterna hirundo) migrate south along the western coast of Europe and Africa, while birds from eastern regions are known to cross the Mediterranean Sea from east to west or migrate along the eastern African coast. The migration route of north European terns wintering along the coast of western Africa was already described using geolocator data, while knowledge about movements of the European inland populations is based only on relatively scarce recoveries of ringed birds.

Methods: We used light-level geolocators in inland Common Tern colonies in Hungary and Croatia to study their migration route and to identify wintering areas along with stopover sites. Results revealed by geolocators were compared with recoveries of ringed birds.

Results: All tracked birds used the east African migration route with autumn stopovers at Lower Nile and in the southern part of the Red Sea, and short spring stopover in Israel. Terns wintered along Kenyan coasts and in the southern Mozambique Channel. Autumn migration lasted four times longer than spring migration.

Conclusions: This is the first geolocator study that describes the east African migration route of the Common Tern. Important stopover sites were identified. More studies of inland populations are needed to better elucidate tern winter movements.
\end{abstract}

Keywords: Inland population, Light-level geolocators, Mozambique Channel, Red Sea, Sterna hirundo, Stopover sites, Wintering area

\section{Background}

Tracking devices are increasingly used in the study of seabird migration, providing detailed information about long-distance journeys which was impossible to gain using other methods such as observations or ringing (Brooke 2018). Many seabird species spend their entire non-breeding season far from land, therefore migration strategies and non-breeding areas were largely unknown prior to the development of tracking devices. Light-level

*Correspondence: jkralj@hazu.hr

${ }^{1}$ Institute of Ornithology, Croatian Academy of Sciences and Arts, Gundulićeva 24, 10000 Zagreb, Croatia

Full list of author information is available at the end of the article geolocators produce less precise location data compared to GPS tracking, but precision is adequate enough for the objectives of large-scale tracking, and were already used for studying tern migration (Egevang et al. 2010; Nisbet et al. 2011; McKnight et al. 2013).

The Common Tern (Sterna hirundo) breeds in both coastal and inland habitats of the Holarctic. It is a longdistance migrant, wintering along sea coasts in the southern hemisphere. Two main migration routes of European breeders were revealed by recoveries of ringed birds. Based on these recoveries, most Common Terns appear to migrate south along the western coast of Europe and Africa. Populations from central and eastern Europe either cross the Mediterranean Sea from east to west 
and join the west African route, or migrate across the eastern Mediterranean, the Red Sea, and along eastern African coast (Cramp and Simmons 2006). Recoveries of inland Common Terns breeding in Central Europe are scarce. Recoveries of Hungarian terns showed predominantly the use of the southeastern route, following the Danube to the western coast of the Black Sea, and southward along the eastern coast of the Mediterranean Sea, with wintering areas along the coast of Mozambique and Republic of South Africa (Szinai 2009). The limited number of recoveries of Croatian birds indicate the use of the western route with wintering areas in the Republic of South Africa (Kralj 2013).

Previous geolocator studies on Common Terns were conducted on populations breeding along marine coasts of North America (Nisbet et al. 2011) and Europe (Becker et al. 2016), on the Azores (Neves et al. 2015) and on North American lakes (Bracey et al. 2018). Geolocator tracking of German North Sea populations already helped to describe the migration route, stopover locations and wintering sites along the coast of western Africa (Becker et al. 2016). However, movements of European inland populations breeding along middle reaches of rivers are less known. In Europe, rivers are among the scarcest and the most threatened habitats (European Environment Agency 2015). Inland populations of Common Terns are threatened by changes of river hydrology: river management causes frequent breeding failures (Atamas and Tomchenko 2015) or complete destruction of breeding habitats. In many countries terns are therefore largely dependent on artificial habitats (Scharf 1981; Bogliani et al. 1982; Becker and Sudmann 1998). Readiness to accept artificial habitats has helped recovery of inland populations in Europe after the collapses during the 19th and 20th centuries (Glutz von Blotzheim and Bauer 1999). However, to provide long-term nesting opportunities, man-made breeding habitats need regular maintenance. Terns can therefore only be preserved by re-establishing and conserving suitable habitats (Becker and Sudmann 1998). Climate change is also expected to affect Common Tern breeding grounds: the Common Tern's simulated future potential distribution, based on the relationship between its breeding distribution and local climate, forecasts loss of inland habitats and a patchier distribution in continental Europe (Huntley et al. 2007). Effective conservation of long-distance migrants requires the understanding of their full annual cycle (Marra et al. 2015). Tracking of individual birds is of great importance in identifying important stopover locations during migration and wintering. As Common Terns face potential risks, such as decline in fish populations, adverse weather, sea pollution or outbreaks of diseases (Feare et al. 2007; Croxall et al. 2012; Le Corre et al.
2012), such knowledge is crucial in developing strategies for conservation actions at sites used during the nonbreeding season.

The aims of this study were (1) to elucidate migration routes used by Common Terns belonging to European inland populations, and (2) to identify main stopover sites and wintering areas. Based on previous ring recovery data, we expected Common Terns from Hungarian colonies to use the eastern flyway and birds from Croatian colonies to use the western one. Apart from Israel, no other stopover site was known for inland populations (Cramp and Simmons 2006). In long-lived species as terns, population trends are more likely to be influenced by survival rates than annual changes in productivity (Bracey et al. 2018), therefore identification of stopover and wintering sites is an important step in threat assessment. Here we present the results of two geolocator tracking projects of Central European inland Common Tern colonies; to our knowledge, this is the first geolocator study of an inland population of the species in Europe.

\section{Methods}

We studied the migration of two inland Common Tern colonies: one breeding on lakes of the lagooning facility near the town of Várpalota (Hungary), and the other along the river Sava and surrounding gravel pits in the vicinity of Zagreb (Croatia). The Hungarian study colony of 60 pairs nests on three artificial breeding platforms on two waterbodies: Nagybivalyos and Inota30 fishponds $\left(47^{\circ} 11^{\prime} \mathrm{N}, 18^{\circ} 10^{\prime} \mathrm{E}\right)$. Platforms hold a gravel bed for nesting and artificial shelters are provided. Although these are non-natural waterbodies with regular human presence, the characteristics and diversity of bird taxa are of good quality habitat. Croatian breeding ground comprises the area of $250 \mathrm{~km}^{2}$ that holds about 120 breeding pairs. We studied the colony on a gravel island at Rakitje gravel-pit $\left(45^{\circ} 48^{\prime} \mathrm{N}, 15^{\circ} 50^{\prime} \mathrm{E}\right)$, the biggest and the most stable colony in that area.

A total of 91 adult Common Terns (18 in Hungary and 73 in Croatia) were captured on their nests during the incubation stage between late May and early July in 2014-2018. Walk-in traps and target activated drop traps were used to capture breeding adults. After ringing the birds with metal and plastic rings, mass was measured for pre-deployment and recovery comparison. In Hungary, we fitted 5 and 2 birds in 2014 and 2016, respectively, with archival light level recorders (MK5090, Biotrack Ltd) mounted on plastic leg rings. In Croatia, similar loggers (Intigeo-W65A9-SEA, Migrate Technology Ltd) were deployed on 10 birds per year in 2016 and 2017. Mass of the ring, logger, tie, and glue was $1.35 \mathrm{~g}$ (MK5090) and $0.95 \mathrm{~g}$ (Intigeo-W65A9-SEA), representing $1.2 \%$ and 
$0.8 \%$ of the mean body mass of adult birds in these populations, which corresponds with international standards (Bridge et al. 2011). Biotrack loggers recorded light intensity every $2 \mathrm{~min}$, whereas Intigeo loggers were programmed to sample light intensity every minute with maximum light recorded every $5 \mathrm{~min}$. Intigeo loggers also collected dry/wet data every $6 \mathrm{~s}$ with a number of wet samples recorded every $5 \mathrm{~min}$. Conductivity was set to level $>63$ for 'wets' count, thus recording salt water only. In order to recover the loggers, we attempted to recapture tagged birds during the incubation period after 1 year of logger deployment. Light data was processed using R package BAStag (Wotherspoon et al. 2016) to identify twilight times (sunrise and sunset). We used the light-level thresholds of 1.5 (Biotrack) and 1.0 (Intigeo). Extreme outliers were adjusted manually. We used postdeployment calibration at the breeding colonies, after the incubation phase and prior to migration. Calibration periods were set for each bird individually, with periods of high shading during the daylight determined as incubation phase. For Intigeo loggers, we were able to perform a second calibration at the same location, at the end of the deployment period. We were unable to do so for
Biotrack loggers, as they had stopped working before the terns returned to the breeding area. After identification of twilight times, we employed the $\mathrm{R}$ package FLightR (Rakhimberdiev et al. 2015) to derive location estimates. FLightR uses the curve-fitting method to estimate the positions of birds with a particle filter $\left(10^{6}\right.$ particles) to optimise the position for each twilight (Lisovski et al. 2020). As Common Terns use both inland and coastal habitats, we didn't apply spatial constrains. Salt data helped in distinguishing between migration over land and over the sea. For kernel analysis, stopovers and wintering period were set individually, based on dates of stationary periods from geolocator analysis (Table 1). Kernel densities were calculated for stopovers and wintering period of all individuals using kernelUD function of the adehabitatHR (Calenge 2006) package. The smoothing parameter of the kernel density was computed by the reference (ad-hoc) method. Stopover location analysis (also using FLightR) and geolocator data visualisation were performed according to the online supplementary manual of Lisovski et al. (2020). We plotted the most probable positions and defined stopovers as localities where individual terns spent at least 2 days. We used $R$ packages

Table 1 Phenology of Common Tern migration based on tracks by light-level geolocators

\begin{tabular}{|c|c|c|c|c|}
\hline & Mk001 & Mk006 & Z548 & Z555 \\
\hline Date logger deployed & 27 June 2014 & 8 June 2014 & 31 May 2016 & 7 June 2016 \\
\hline Date logger retrieved/stopped & 4 Nov 2014 & 28 Feb 2015 & 30 May 2017 & 8 June 2017 \\
\hline Number of tracking days & 130 & 267 & 365 & 366 \\
\hline Departure from breeding ground & 17 Aug & 20 Aug & 19 July & 19 July \\
\hline \multicolumn{5}{|l|}{ Arrival to autumn stopover site } \\
\hline Lower Nile & 19 Aug & 22 Aug & - & 23 July \\
\hline Southern Red Sea & 7 Oct & 27 Aug & 26 July & 26 July \\
\hline \multicolumn{5}{|l|}{ No. of days at a stopover site } \\
\hline Lower Nile & 35 & 2 & - & 0 \\
\hline Southern Red Sea & 4 & 110 & 67 & 67 \\
\hline \multicolumn{5}{|l|}{ Departure from stopover site } \\
\hline Lower Nile & 6 Oct & 24 Aug & - & 23 July \\
\hline Southern Red Sea & 11 Oct & $15 \mathrm{Dec}$ & 10 Oct & 10 Oct \\
\hline Arrival to wintering site & 31 Oct & $19 \mathrm{Dec}$ & $26 \mathrm{Oct}$ & 26 Oct \\
\hline Duration of post-breeding migration (days) & 75 & 121 & 99 & 99 \\
\hline Distance travelled during post-breeding migration (km) & 7247 & 7501 & 9117 & 9554 \\
\hline Departure from wintering site & - & - & $16 \mathrm{Mar}$ & $19 \mathrm{Mar}$ \\
\hline Arrival to spring stopover site & - & - & $31 \mathrm{Mar}$ & $31 \mathrm{Mar}$ \\
\hline No. of days at a stopover site & - & - & 5 & 5 \\
\hline Departure from stopover site & - & - & $5 \mathrm{Apr}$ & $5 \mathrm{Apr}$ \\
\hline Arrival to the breeding site & - & - & 9 Apr & 9 Apr \\
\hline Duration of prenuptial migration (days) & - & - & 24 & 21 \\
\hline Distance travelled during prenuptial migration $(\mathrm{km})$ & - & - & 8659 & 9040 \\
\hline
\end{tabular}

Stopover and wintering locations were defined by stationary periods resulting from FLightR analysis. Mk001 and 006 were tagged in Hungary, while Z548 and Z555 in Croatia. Data are available in Movebank repository https://bit.ly/2K7TMLM (CRO) and https://bit.ly/2kyhFmD (HUN) under same IDs 
maps (Becker et al. 2018), mapplots (Gerritsen 2018) and GISTools (Brunsdon and Chen 2014) for geolocator data visualisation. Distance travelled during migration was calculated as the distance between stopover sites as revealed by geolocators. Great-circle (orthodromic) distances between breeding and mean wintering locations were calculated for Hungarian and Croatian birds.

Recoveries of ringed birds were used to compare known migration routes between terns from Hungarian and Croatian colonies and with results revealed by geolocators. In the period between 1910 and 2018, 6371 and 3322 Common Terns were ringed by Budapest and Zagreb ringing schemes respectively. Of these, 1186 and 669 birds were colour-ringed with plastic rings engraved with alphanumeric symbols. As of May 2019, 263 recoveries were processed (111 from Hungary and 152 from Croatia), of which 212 were observations of colour-ringed birds (67 from Hungary and 145 from Croatia). Recoveries of four birds ringed in Israel during migration and observed in Hungary or Croatia are also included in the analysis. In this paper, we analysed long-distance recoveries indicating dispersal and migration, so we excluded recoveries of breeding adults and recoveries with a distance less than $150 \mathrm{~km}$. Repeated observations of the same individuals during the same season were excluded, as they reflect observation effort and will cause bias.

Terns observed during the end of the first calendar year were categorised as juveniles. Birds observed in the second and third calendar year were labelled as immatures, while birds in the 4th year and older were considered to be adults. As Common Terns showed large differences in the timing of migration between years (see Neves et al. 2015; Becker et al. 2016; authors' personal observation), recoveries were assigned into stages of the annual cycle according to both time period and recovery locality. In general, spring migration lasted from March to May, the breeding period from May to early August, post-breeding dispersal and prospecting of immature birds from late June to August, autumn migration from August to November and wintering from December to early March. Recovery data visualisation was performed using QGIS (QGIS Development Team 2016).

\section{Results}

\section{Geolocator data}

Only six loggers were retrieved; two in Hungary in 2015, three in Croatia in 2017 and one in Croatia in 2018. Six more birds with geolocators were observed in Croatia in 2018 and 2019 but as we were not able to identify their nest locations during the incubation period, we could not recapture them. Loggers recovered in Hungary worked for 130 and 267 days. Out of the four loggers recovered in Croatia, two worked during the whole year while the other two worked for less than 1 month and therefore their data was not analysed. Recaptured birds were in good physical condition, without apparent injuries on the legs, although one bird (in Hungary) had mould under the ring holding the logger. There was no significant difference in pre-deployment and recovery weight for tagged terns (paired-sample $t$ test: $t_{\mathrm{df}}=4=0.022$, $p=0.982$ ). The pattern of post-breeding migration and wintering area was revealed from four birds (two from Hungary and two from Croatia).

All four Common Terns took the eastern migratory route (Fig. 1). They left the breeding grounds in midJuly (in 2016) or mid-August (in 2014). Terns reached the eastern Mediterranean shores over land across the Balkan Peninsula and Turkey and continued along the Lower Nile and the Red Sea, further following the eastern coast of Africa. All birds had one long stopover during the autumn migration; one Hungarian bird stayed in the Lower Nile, while the other three stopped in the southern Red Sea (Table 1). Stopovers lasted from August until early October, except for one bird that stayed in the southern Red Sea until mid-December (Additional file 1: Fig. S1). Long stopovers are clearly distinguishable by the lack of changes in both latitude and longitude data (Additional file 2: Fig. S2). Three birds reached wintering grounds in the western Indian Ocean in late October, while one did so in December. Croatian birds wintered along coasts of SE Africa, in the southern Mozambique Channel, $7500 \mathrm{~km}$ from the breeding site, while Hungarian birds wintered some $2000 \mathrm{~km}$ north, along the coast of Kenya, $5800 \mathrm{~km}$ from the breeding site.

Prenuptial migration data originates from two Croatian birds. Their return migration started in mid-March, but both birds moved some $900-1200 \mathrm{~km}$ north in late February and stayed 2 weeks along the coast of northern Mozambique. The birds used a similar route as during the post-breeding migration, but overall moved faster with one short (5-day) stopover in Israel. Birds reached the breeding grounds on 9 April. Post-breeding migration lasted $98.5 \pm 18.8$ days (mean $\pm \mathrm{SD}, n=4$ ) and prenuptial migration 24 and 21 days $(n=2)$. Salt water signals from Intigeo tags confirmed that, after reaching the Mediterranean Sea in August, birds from Croatia predominantly used marine habitats during the entire non-breeding period. The mean distance travelled during post-breeding migration was $8354 \pm 1154 \mathrm{~km}($ mean $\pm \mathrm{SD}, n=4)$ and for return migration 8659 and $9040 \mathrm{~km}(n=2)$.

\section{Ringing recoveries data}

Thirty-one long-distance recoveries (12 Hungarianrelated and 19 Croatian-related) of ringed Common Terns were analysed (Fig. 2; Additional file 3: Table S1). Majority of recoveries characterize the post-breeding 


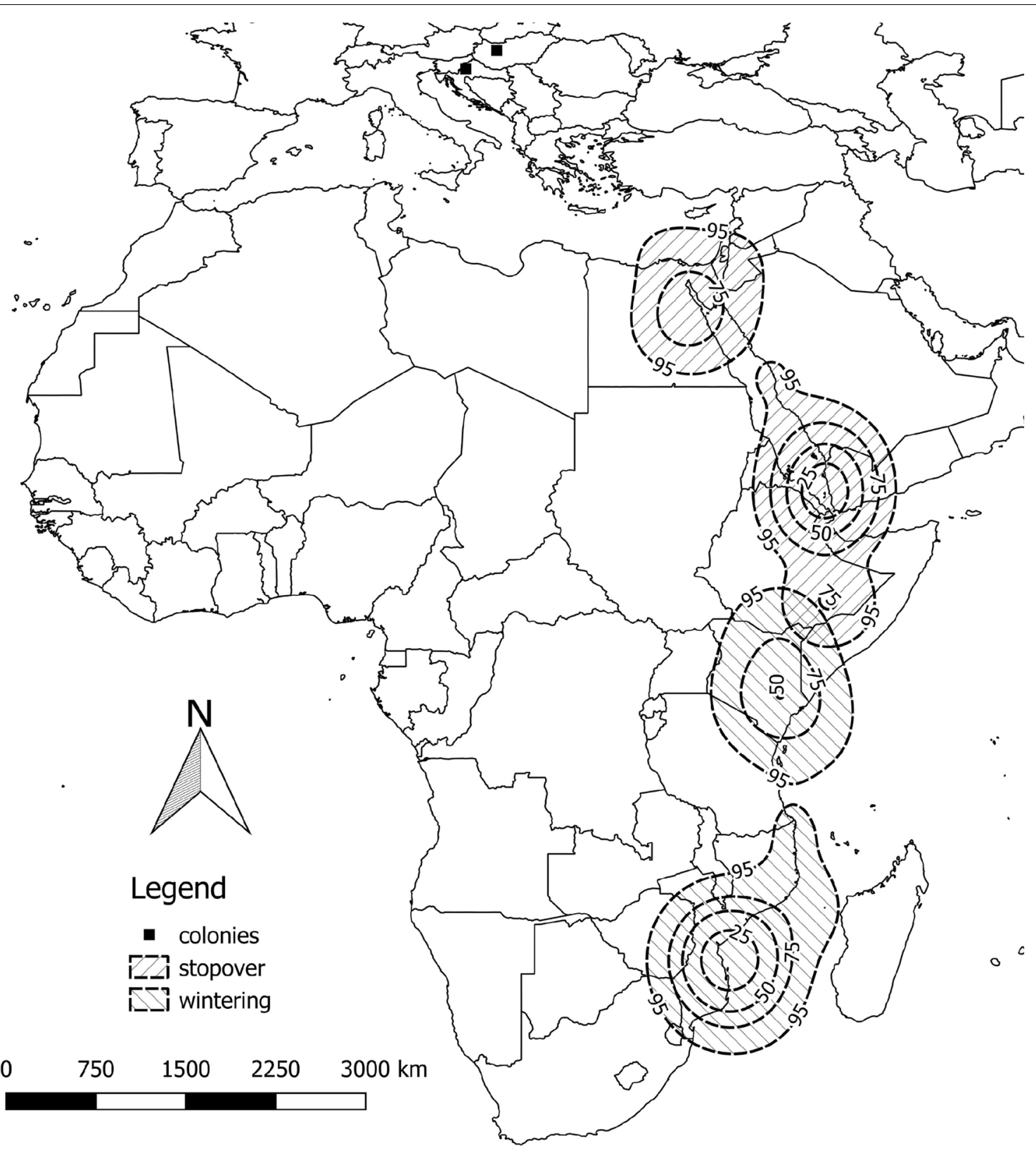

Fig. 1 Stopover sites and wintering area of four Common Terns from Hungary and Croatia, tracked with light-level geolocators between 2014 and 2017. Black squares indicate breeding sites. Kernel densities are indicated by dashed line

(August-October) and spring migration (April-May), followed by dispersal or prospecting (June-August). Winter recoveries (January-March) were reported for immature birds only (Table 2). Hungarian-related birds mostly used the southeastern route, with observations from Serbia, Romania, Ukraine, Greece and Israel suggesting a route along the Danube, the Black Sea, the Bosporus, and the Mediterranean Sea. However, two recoveries in Italy indicate the use of the southwestern route. Wintertime recoveries were reported from Mozambique and the Republic of South Africa. Croatian-related recoveries in Italy, Tunisia, and Senegal indicated the southwestern route, but three recoveries from Serbia, two from Israel, and one from Jordan confirmed the migration towards the eastern Mediterranean. The only recovery in the wintering period was from the Republic of South Africa. The difference between the use of SE and SW route between 


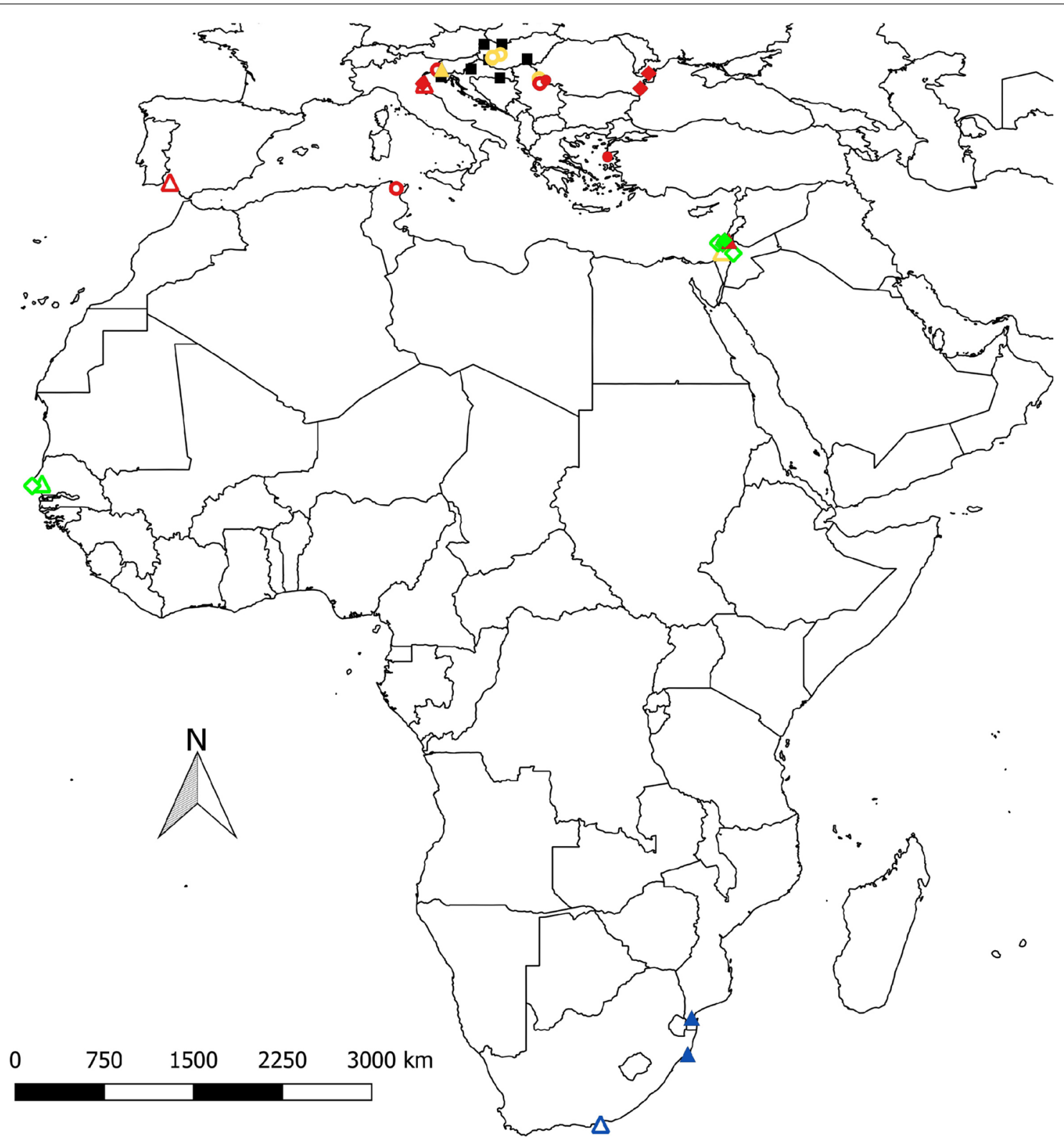

Fig. 2 Hungarian- and Croatian-related long-distance (>150 km) recoveries of Common Terns. Recoveries of adult breeding birds are excluded. Black squares indicate breeding sites. Closed symbols represent Hungarian-related and open symbols Croatian-related recoveries. Colour indicates stages of the annual cycle: green—spring migration, yellow_-post-breeding dispersal and prospecting, red_-autumn migration, blue—wintering. A circle was used to represent first-year birds, triangle for immatures and rhombus for adults (Hungarian-related data was provided by BirdLife Hungary)

Hungarian and Croatian Common Terns was not significant (Fisher's Exact Test, $p=0.107$ ).

\section{Discussion}

Although Common Terns breeding in Central Europe have been known to use the southeastern flyway (Cramp and Simmons 2006), we present the first detailed description of their east African migration route. Two stopover sites used during autumn migration were identified: Lower Nile and the southern part of the Red Sea, and we also confirmed a stopover in Israel during spring migration (Cramp and Simmons 2006; Kiat 2016). Terns stayed in the eastern part of the Nile Delta, around Lake Manzala, which is assigned as an Important Bird and 
Table 2 Summary of Hungarian- and Croatian-related recoveries of Common Terns, indicating the direction of migration

\begin{tabular}{|c|c|c|c|c|c|}
\hline \multirow{2}{*}{ Age at recovery } & \multirow[t]{2}{*}{ Annual cycle stage } & \multirow[t]{2}{*}{ Number of recoveries } & \multicolumn{3}{|c|}{ Number of recoveries with regard to direction } \\
\hline & & & SW and W & SE and $\mathrm{E}$ & Other \\
\hline \multirow[t]{2}{*}{ Juvenile } & Dispersal & 6 & & 2 & 4 \\
\hline & Autumn migration & 7 & 3 & 4 & \\
\hline \multirow[t]{4}{*}{ Immature } & Wintering & 3 & 1 & 2 & \\
\hline & Spring migration & 1 & 1 & & \\
\hline & Dispersal/prospecting & 2 & 1 & 1 & \\
\hline & Autumn migration & 2 & 2 & & \\
\hline \multirow[t]{2}{*}{ Adult } & Spring migration & 6 & 1 & 5 & \\
\hline & Autumn migration & 4 & 1 & 3 & \\
\hline Total & & 31 & $10(32.3 \%)$ & $17(54.8 \%)$ & $4(12.9 \%)$ \\
\hline
\end{tabular}

The direction of migration indicated the direction from the ringing place. "Other" includes recoveries during dispersal, directed between NW and NE. For the age and stages of the annual cycle, see "Methods"

Biodiversity Area significant for migration and wintering of waterbirds (Evans and Fishpool 2001). It is a brackish lake with more than 1000 islands, with main habitats being reed-swamps, saltmarshes and sandy areas (BirdLife 2019). Of four tracked terns, one stayed in the Lower Nile for a longer period and one seemed not to stop there at all. All four birds stopped in the southern Red Sea area, three of them for over 2 months. The southern part of the Red Sea is rich in nutrients that are brought by windinduced horizontal advection from the Gulf of Aden during the winter monsoon season (Raitsos et al. 2015). The productivity of the southern Red Sea therefore increases at the beginning of October and stays high during winter months. However, three of four tracked terns left the area at the beginning of October, about the time when nutrients normally start to increase. We therefore presume that birds used this stopover site in order to avoid strong southwestern summer monsoons (Clemens et al. 1991) blowing in the direction opposite to their migration, and continued their movement with a tailwind of north-eastern winter monsoons. Similar to other terns with flapping flight, Common Terns are very receptive to wind speed and direction (Barrett 2016), and stopping in the southern Red Sea to wait for favourable wind conditions can minimize their travel costs during the final part of their autumn migration. Although a departure from that site coincides with the period of 3 weeks around the autumn equinox, when latitudes are difficult to determine using data from light level geolocation (Porter and Smith 2013), quick changes in longitude obvious in October indicate the start of a consecutive migration step (Additional file 2: Fig. S2). The longest stationary period during migration, as resulting from FLightR analysis, was 110 days, spent by the tern Mk006 at the southern Red Sea. However, during that period, a part of locations fell $750 \mathrm{~km}$ further south, near the Shebelle River in Ethiopia.
Whether that latitude change, visible from Fig. 1 and Additional file 2: Fig. S2b, was erroneous or not, has to be further studied. The period spent at stopover sites was much longer in inland European Common Terns than in German North Sea populations, in which the longest stay at stopover was less than 1 month (Becker et al. 2016). Some inland North American Common Terns also have long stopovers: mean duration at stopovers was 21 and maximum 71 days (Bracey et al. 2018).

Terns tagged in Croatia wintered in the southern Mozambique Channel. That area was already identified as one of the hotspots for foraging seabirds in the tropical western Indian Ocean (Le Corre et al. 2012). Strong eddy activity typical for that area induces offshore transport of nutrient-rich coastal waters to the nearsurface layer, increasing productivity (José et al. 2016). Although productivity is lower during the (northern) winter, coastal waters still have high chlorophyll concentrations (José et al. 2016), providing good feeding opportunities for wintering terns. Hungarian terns were found wintering along the coast of Kenya, close to the Tana River. Tana River delta is a Ramsar site, hosting a large number of waterbirds, including several tern species (RSIS 2019). Two main threats for foraging seabirds were identified in the Mozambique Channel and Kenyan coast: oil pollution due to maritime traffic and intensive industrial fishing (Le Corre et al. 2012). Industrial fishing is developing in the western Indian Ocean causing a threat of over-exploitation of the fishstock, especially predatory fish such as tuna. As many other seabird species, Common Terns were shown to forage in aggregation with schools of tuna driving small fish to the surface (Goyert et al. 2014). The decline in predatory fish populations is supposed to have serious impacts on the seabirds using that foraging strategy (Feare et al. 2007). 
Both birds tracked during prenuptial migration shortly stopped in Israel in early April, a stopover that was not used by either of the tracked birds during post-breeding migration. This data is in accordance with earlier findings indicating Israel as an important stopover site for Central European Common Tern populations during spring migration, but rendering its importance lower in autumn (Cramp and Simmons 2006; Kiat 2016). As a result of long stopovers, post-breeding migration lasted more than four times longer than prenuptial migration. Similar results were found for inland Common Terns in North America (Bracey et al. 2018). Faster spring migration is a general pattern among birds (Nilsson et al. 2013), however in case of Common Terns the opposite was found for several individuals of a German North Sea population wintering along the West African coast (Becker et al. 2016). The northward movement of both Croatian birds in late February could be described either as winter movement or the start of the prenuptial migration; late February is a period of departure from wintering grounds for terns breeding in Germany and wintering along east African coasts (Becker et al. 2016). On the other hand, substantial movements during winter were reported for other Common Tern populations (Neves et al. 2015; Bracey et al. 2018). The area where Croatian birds spent late February and early March lays further south than the wintering area of two Hungarian terns revealed by this study. This suggests that Central European terns utilize a large span of the Kenyan and Mozambique coasts as wintering grounds. Further studies are therefore needed to elucidate winter movements of Common Terns.

Although using the same east African flyway, there were some differences between Hungarian and Croatian terns' migration pattern. The two birds from Croatia had a very similar migration pattern, and were probably migrating in the same flock. Similarly, two colour-ringed birds from the same colony were observed together during dispersion or autumn migration on several occasions (Additional file 3: Table S1). The departure of Hungarian terns in 2014 was almost a month later than the departure of Croatian terns in 2016. This difference is more likely to be related to individual variations within the same colony or interannual changes than to the breeding site. For example, changes of water level affect the start of the breeding season while clutch failure and renesting affect its termination, both capable of causing the difference in departure date. Individual and annual differences in the timing of departure were recorded by several studies of Common and Arctic Tern Sterna paradisaea migration (Becker et al. 2016; Bracey et al. 2018; Redfern and Bevan 2019).

There are several possible explanations for the differences in wintering areas between Hungarian and
Croatian birds. As one Hungarian logger stopped in early November, it is possible that this bird did not reach its final wintering area during that time. Furthermore, interannual changes in the primary productivity in the Western Indian Ocean affect phytoplankton-feeding fishes (Monticelli et al. 2007) and could cause differences in the abundance of tern prey, which might affect their choice of wintering area. Although many seabirds have high wintering site fidelity, it is known that some birds showed flexibility in wintering site, stopover behaviour and migratory schedule (Dias et al. 2011). Recoveries of a Hungarian-ringed bird in Mozambique and Kwazulu-Natal province of the Republic of South Africa indicate that at least some birds in some years reach the Mozambique Channel. However, we cannot exclude the possibility of some level of migratory connectivity (i.e. segregation of wintering areas of birds from different colonies), as recorded for the Artic Tern (Sterna paradisaea) (Fijn et al. 2013). Further studies of several Central European populations are needed to get a better understanding of temporal and spatial differences in migration of Central European Common Terns.

Studies based on ring recoveries or resightings are affected by bias caused by spatial and temporal heterogeneity in ring re-encounter probability (Korner-Nievergelt et al. 2012). Therefore, they reflect both bird distribution and the number and activity of potential observers. In spite of the considerable number of terns ringed in Hungary and Croatia, recovery data are limited. Observations from Italy, Spain, Tunisia and Senegal indicate the use of the southwestern route, while recoveries in Serbia, Romania, Ukraine, Jordan and Israel confirmed the movement of terns towards the eastern Mediterranean. However, a great part of recoveries belong to immature birds, whose movements prior to returning to breeding grounds are insufficiently known. Therefore, they might represent either a migration route or wandering of immature birds. The number of long-distance recoveries from other Central European countries is also small but indicates migration routes used. Common Terns breeding in Czechia migrate mostly in a southwestern direction to the western Mediterranean and further along the western coast of Africa, with recoveries in Liberia and DR Congo. However, an autumn recovery in Hungary of a Common Tern from southern Moravia, together with a spring recovery of a bird ringed in Slovakia and found on the Evros delta in Greece, suggests the use of the south-eastern migration route (Krestova 2008). The only recovery of a bird hatched in the Adriatic population in Croatia was from a subadult (3rd year) bird found in September 2000 in Huelva, Spain (Kralj 2013), confirming east-west migration through the Mediterranean Sea. Numerous recoveries of Common Terns breeding on the 
other side of the Adriatic Sea, in northern Italy, showed the use of the western route, with recoveries from Spain to Gabon (Spina and Volponi 2008).

In earlier studies, the use of light-level geolocators attached to the tarsus of Common Terns showed no negative effect on the behaviour and fitness of tagged birds (Kürten et al. 2019). In our study, we found no weight loss or visible injuries on tagged birds. The low ratio of retrieved geolocators $(22 \%)$ is a result of the relative instability of studied colonies compared with coastal ones (Becker et al. 2016). Riverine breeding sites are often less stable than coastal ones because of interannual water level changes and predation (Scharf 1981; Bogliani et al. 1982). In Croatia, recoveries of adult birds showed frequent changes of breeding colonies between years, and in 2018 even within the breeding season (Martinović et al. 2019). Between 2016 and 2018 Common Terns bred on seven different islands in the study area: two sites were occupied in 2016, three sites in 2017 when low water level created additional islands and four in 2018 when water level was exceptionally high and the main island at Rakitje gravel pit was submerged and was unsuitable for breeding until mid-June. Furthermore, in the middle of the breeding season of 2016, all nests were destroyed on all platforms at the Hungarian colony, presumably by an Otter (Lutra lutra). This prevented us from deploying all available loggers, and from retrieving further loggers deployed in 2014. This predation event might also have been the reason for a remarkably low breeding pair density in 2017.

In many studies, geolocator data yielded supplementary information about non-breeding distribution and timing of migration already known from recoveries of ringed birds, but in some cases, different migration patterns were revealed (Korner-Nievergelt et al. 2012). During this study, geolocators revealed the use of east African route for Croatian birds, a fact that had not been obvious from recoveries of ringed birds processed before 2010 (Kralj 2013). Retrieved data of four birds enabled us to outline the migration strategy of Central European inland breeding Common Terns using the east African route for the first time. Stopover areas at Lower Nile and the southern Red Sea were identified, as well as wintering sites along the Kenyan coast and in the southern Mozambique Channel.

Identified stopover and wintering sites face multiple threats either currently or potentially: Lake Manzala in the Nile delta is threatened by pollution from wastewaters, increasing salinity, land reclamation and illegal killing of birds (Evans and Fishpool 2001). The southern Red Sea is generally in a healthy state and lengthy stopovers confirm that the area is favourable for foraging Common Terns. However, due to its semi-enclosed nature and the petroleum-industry of economies in the region, it faces high risk of oil pollution (Gladstone et al. 1999). The Mozambique Channel and Kenyan coast are also threatened by oil pollution and overfishing (Le Corre et al. 2012). Climate change, identified as one of the greatest threats to Common Terns worldwide (Palestis 2014; Bracey et al. 2018), might also have serious impacts on wintering areas in the Indian Ocean. The relatively cool and productive western Indian Ocean is reported to be undergoing a long-term warming trend, with anticipated effects on monsoon circulation and marine food webs (Roxy et al. 2014). Surprisingly, warming of the Indian Ocean is shown to increase productivity of the Red Sea due to stronger winds amplifying the northward advection of nutrient-rich waters from the Gulf of Aden (Raitsos et al. 2015). It is possible that the southern Red Sea will thus become an even more important feeding area for European Common Terns.

Differences in migration between Hungarian and Croatian breeders point to the importance of further studying the migration of Central European populations of the Common Tern. This, along with exploring their exposure to environmental factors and threats along the migration route, might help stakeholders in designing and implementing conservation measures for the protection of long-distance migratory seabirds along their migration routes.

\section{Conclusions}

This is the first geolocator study of European inland Common Tern colonies and the first one that describes the east African migration route. It identifies an important autumn stopover sites in the Lower Nile and southern Red Sea. More studies of inland colonies are needed to better elucidate Common Tern migration and winter movements, eventually helping to identify potential threats during the non-breeding season.

\section{Supplementary information}

Supplementary information accompanies this paper at https://doi. org/10.1186/s40657-020-00191-z.

Additional file 1: Fig. S1. Tracks of four Common Terns as estimated from light-level geolocation data by FLightR with GPS positions based on medians of twilight positions.

Additional file 2: Fig. S2. Individual light-level geolocation data. Medians of twilight positions are shown (black line) with accompanying quartile ranges (dark grey shade) and 95\% credible intervals (light-grey shade).

Additional file 3: Table S1. List of recoveries of Common Terns related to Croatia and Hungary between 1956 and 2019 (Hungarian-related data was provided by BirdLife Hungary).

Acknowledgements

We thank the staff at Sali-Dent Ltd. for the assistance in fitting the loggers to the rings for the Hungarian deployment. We extend our thanks to the 
members of the MTA-PE Evolutionary Ecology Research Group and to BirdLife Hungary for the help in the maintenance of breeding platforms in Hungary and the Public Institution "Green Ring" for maintaining the breeding colony at Rakitje, Croatia. We also thank two anonymous reviewers for their valuable comments.

\section{Authors' contributions}

Field study in Hungary was conducted by BP, SS and PS, while in Croatia by $J K, L J$ and MM. MM and JK analysed geolocator data. JK and BP drafted the manuscript. MM prepared maps and all authors shared in editing and revising the manuscript. All authors read and approved the final manuscript.

\section{Funding}

Geolocators in Hungary were co-financed by University of Pannonia, BirdLife Hungary, and Járipatak-menti Természetvédelmi és Vadgazdálkodási Közhasznú Egyesület. The geolocator study of Croatian terns was co-financed by the Public Institution "Green Ring" (Grant Number: 612-07/16-16/), while colour ringing was co-financed by the Environmental Protection and Energy Efficiency Fund (EPEEF).

\section{Availability of data and materials}

The datasets generated and/or analysed during the current study are available in the Movebank repository, https://bit.ly/2K7TMLM (CRO) and https://bit. ly/2kyhFmD (HUN).

\section{Ethics approval and consent to participate}

Tagging of Common Terns was carried out with the approval of the National Inspectorate for Environment, Nature and Water in Hungary (permission no.: 14/10094-6/2013) and of the Ministry of Environment and Energy of the Republic of Croatia (Nos. 517-07-1-1-1-16-3 and 517-07-1-1-1-17-4).

\section{Consent for publication}

Not applicable.

\section{Competing interests}

The authors declare that they have no competing interests.

\section{Author details}

${ }^{1}$ Institute of Ornithology, Croatian Academy of Sciences and Arts, Gundulićeva 24, 10000 Zagreb, Croatia. ${ }^{2}$ Poultry Centre, Croatian Veterinary Institute, Heinzelova 55, 10000 Zagreb, Croatia. ${ }^{3}$ Balaton-felvidéki National Park Directorate, Csopak 8229, Hungary. ${ }^{4}$ Department of Limnology, University of Pannonia, Veszprém 8200, Hungary. ${ }^{5}$ Balaton Limnological Institute, MTA Centre for Ecological Research, Tihany 8237, Hungary.

Received: 17 September 2019 Accepted: 28 February 2020 Published online: 11 March 2020

\section{References}

Atamas NS, Tomchenko OV. Influence of spring flood's water level on the distribution and numbers of terns (on example of lower Desna River). Vestn Zool. 2015;49:439-46.

Barrett RT. Upwind or downwind: the spring arrival of Arctic Terns Sterna paradisaea at Troms, North Norway. Ringing Migr. 2016;31:23-9.

Becker PH, Sudmann SR. Quo vadis Sterna hirundo? Vogelwelt. 1998;119:293-304.

Becker PH, Schmaljohann H, Riechert J, Wagenknecht G, Zajková Z, GonzálezSolís J. Common Terns on the East Atlantic Flyway: temporal-spatial distribution during the non-breeding period. J Ornithol. 2016;157:927-40.

Becker RA, Wilks AR, Brownrigg R, Minka TP, Deckmyn A. Maps: draw geographical maps. version 3.3.0. 2018. https://CRAN.R-project.org/packa ge=maps. Accessed 19 July 2019.

BirdLife International: Important Bird Areas factsheet: Lake Manzala. 2019. http://www.birdlife.org. Accessed 1 Apr 2019.

Bogliani G, Barbieri F. Nidificazione di sterna comune, Sterna hirundo, e fraticello, S. albifrons, sul fiume Po. Riv Ital Orn. 1982;52:91-109.

Bracey A, Lisovski S, Moore D, McKellar A, Craig E, Matteson S, et al. Migratory routes and wintering locations of declining inland North American Common Terns. Auk. 2018;135:385-99.
Bridge ES, Thorup K, Bowlin MS, Chilson PB, Diehl RH, Fléron RW, et al. Technology on the move: recent and forthcoming innovations for tracking migratory birds. Bioscience. 2011;61:689-98.

Brooke M. Far from land. The mysterious lives of seabirds. Princeton: Princeton University Press; 2018

Brunsdon C, Chen H. GISTools: Some further GIS capabilities for R. version 0.7-4. 2014. https://CRAN.R-project.org/package=GISTools. Accessed 19 July 2019.

Calenge $C$. The package adehabitat for the R software: tool for the analysis of space and habitat use by animals. Ecol Model. 2006;197:1035.

Clemens S, Prell W, Murray D, Shimmield G, Weedon G. Forcing mechanisms of the Indian Ocean monsoon. Nature 1991;353:720-25.

Cramp S, Simmons KEL. BWPi: birds of the Western Palearctic interactive 2.0.1. (DVD-ROM). Sheffield: BirdGuides Ltd; 2006.

Croxall JP, Butchart SHM, Lascelles B, Stattersfield AJ, Sullivan B, Symes A, et al. Seabird conservation status, threats and priority actions: a global assessment. Bird Conserv Int. 2012;22:1-34.

Dias MP, Granadeiro JP, Phillips RA, Alonso H, Catry P. Breaking the routine: individual Cory's shearwaters shift winter destinations between hemispheres and across ocean basins. P Roy Soc B Biol Sci. 2011;278:1786-93.

Egevang C, Stenhouse IJ, Phillips RA, Petersen A, Fox JW, Silk JRD. Tracking of Arctic terns Sterna paradisaea reveals longest animal migration. Proc Natl Acad Sci. 2010;107:2078-81.

European Environment Agency. State of nature in the EU-results from reporting under the nature directives 2007-2012. EEA Technical report 2; 2015.

Evans MI, Fishpool LDC. Important bird areas in Africa and associated islands: priority sites for conservation. Newbury: Pisces Publications, Birdlife International; 2001.

Feare CJ, Jaquemet S, Le Corre M. An inventory of Sooty Terns (Sterna fuscata) in the western Indian Ocean with special reference to threats and trends. Ostrich. 2007;78:423-34.

Fijn RC, Hiemstra D, Phillips RA, van der Winden J. Arctic Terns Sterna paradisaea from the Netherlands migrate record distances across three oceans to Wilkes Land, East Antarctica. Ardea. 2013;101:3-12.

Gerritsen H. mapplots: Data Visualisation on Maps. version 1.5.1. 2018. https:// CRAN.R-project.org/package=mapplots. Accessed 19 July 2019.

Gladstone W, Tawfiq N, Nasr D, Andersen I, Cheung C, Drammeh H, et al. Sustainable use of renewable resources and conservation in the Red Sea and Gulf of Aden: issues, needs and strategic actions. Ocean Coast Manag. 1999:42:671-97.

Glutz von Blotzheim U, Bauer K. Handbuch der Vögel Mitteleuropas. Band 8/II, Charadriiformes (3. Teil). Wiesbaden: AULA Verlag; 1999.

Goyert HF, Manne LL, Veit RR. Facilitative interactions among the pelagic community of temperate migratory terns, tunas and dolphins. Oikos. 2014;123:1400-8.

Huntley B, Green RE, Collingham YC, Wilis SG. A climatic atlas of European breeding birds. Barcelona: Durham University, The RSPB and Lynx Edicions; 2007. p. 227.

José YS, Penven P, Aumont O, Machu E, Moloney CL, Shillington F, et al. Suppressing and enhancing effects of mesoscale dynamics on biological production in the Mozambique Channel. J Mar Syst. 2016;158:129-39.

Kiat Y. Ringing data summary. Isr Bird Ringing J. 2016;2016:3-10.

Korner-Nievergelt F, Jenni L, Tøttrup AP, Pasinelli G. Departure directions, migratory timing and non-breeding distribution of the Red-backed Shrike Lanius collurio: do ring re-encounters and light-based geolocator data tell the same story? Ringing Migr. 2012;27:83-93.

Kralj J. Sterna hirundo. In: Kralj J, Barišić S, Tutiš V, Ćiković D, editors. Croatian bird migration atlas. Zagreb: HAZU; 2013. p. 114-5.

Krestova M. Sterna hirundo. In: Cepák J, Klvaňa P, Škopek J, Schröpfer L, Jelínek M, Hořák D, et al., editors. Czech and Slovak bird migration atlas. Praha: Aventinum; 2008. p. 225-6.

Kürten N, Vedder O, González-Solís J, Scgmaljohann H, Bouwhuls S. No detectable effect of light-level geolocators on the behaviour and fitness of a long-distance migratory seabird. J Ornithol. 2019;160:1087-95.

Le Corre M, Jaeger A, Pinet P, Kappes MA, Weimerskirch H, Catry T, et al. Tracking seabirds to identify potential Marine Protected Areas in the tropical western Indian Ocean. Biol Conserv. 2012;156:83-93.

Lisovski S, Bauer S, Briedis M, Davidson SC, Dhanjal-Adams KL, Hallworth MT, et al. Light-level geolocator analyses: a user's guide. J Anim Ecol. 2020;89:221-36. 
Marra PP, Cohen EB, Loss SR, Rutter JE, Tonra CM. A call for full annual cycle research in animal ecology. Biol Lett. 2015;11:20150552.

Martinović M, Galov A, Svetličić I, Tome D, Jurinović L, Ječmenica B, Basle T, Božič $L$, Kralj J. Prospecting of breeding adult Common terns in anunstable environment. Ethol Ecol Evol. 2019;31:457-68.

McKnight A, Allyn A, Duffy DC, Irons DB. 'Stepping stone' pattern in Pacific Arctic tern migration reveals the importance of upwelling areas. Mar Ecol Prog Ser. 2013;491:253-64.

Monticelli D, Ramos JA, Quartly GD. Effects of annual changes in primary productivity and ocean indices on breeding performance of tropical roseate terns in the western Indian Ocean. Mar Ecol Prog Ser. 2007;351:273-86.

Neves VC, Nava CP, Cormons M, Bremer E, Castresana G, Lima P, et al. Migration routes and non-breeding areas of Common Terns (Sterna hirundo) from the Azores. Emu. 2015;115:158-67.

Nilsson C, Klaassen RH, Alerstam T. Differences in speed and duration of bird migration between spring and autumn. Am Nat. 2013;181:837-45.

Nisbet ICT, Mostello CS, Veit RR, Fox JW, Afanasyev V. Migrations and winter quarters of five Common Terns tracked using geolocators. Waterbirds. 2011;34:32-9.

Palestis BG. The role of behavior in tern conservation. Curr Zool. 2014;60:500-14.

Porter R, Smith PA. Techniques to improve the accuracy of location estimation using light-level geolocation to track shorebirds. Wader Study Group Bull. 2013;120:147-58.

QGIS Development Team. QGIS Geographic Information System. version 2.14.21-Essen. Open Source Geospatial Foundation Project 2016. http:// qgis.osgeo.org.
Raitsos DE, Yi X, Platt T, Racault M-F, Brewin RJW, Pradhan Y, et al. Monsoon oscillations regulate fertility of the Red Sea: monsoons regulate Red Sea greenness. Geophys Res Lett. 2015;42:855-62.

Rakhimberdiev E, Winkler DW, Bridge E, Seavy NE, Sheldon D, Piersma T, et al. A hidden Markov model for reconstructing animal paths from solar geolocation loggers using templates for light intensity. Mov Ecol. 2015;3:25.

Redfern CPF, Bevan RM. Overland movement and migration phenology in relation to breeding of Arctic Terns Sterna paradisaea. Ibis. 2019. https:// doi.org/10.1111/ibi.12723.

Roxy MK, Ritika K, Terray P, Masson S. The curious case of Indian Ocean warming. J Clim. 2014;27:8501-9.

RSIS: Ramsar site information services. 2019. https://rsis.ramsar.org/ris/2082. Accessed 15 May 2019.

ScharfWC. The significance of deteriorating man-made island habitats to Common Terns and Ring-billed Gulls in the St. Mary's River, Michigan. Col Waterbirds. 1981;4:155-9.

Spina F, Volponi S. Atlante della migrazione degli uccelli in Italia. I non-Passeriformi. Roma: ISPRA; 2008.

Szinai P. Common Tern Sterna hirundo. In: Csörgő T, Karcza Z, Halmos G, Magyar G, Gyurácz J, Szép T, et al., editors. Hungarian Bird Migration Atlas. Budapest: Kossuth Kiadó; 2009. p. 343-4.

Wotherspoon S, Sumner M, Lisovski S. BAStag: basic data processing for light based geolocation archival tags. version 0.1.3. 2016. https://rdrr.io/githu b/SWotherspoon/BAStag/. Accessed 12 Sept 2018.
Ready to submit your research? Choose BMC and benefit from:

- fast, convenient online submission

- thorough peer review by experienced researchers in your field

- rapid publication on acceptance

- support for research data, including large and complex data types

- gold Open Access which fosters wider collaboration and increased citations

- maximum visibility for your research: over $100 \mathrm{M}$ website views per year

At BMC, research is always in progress.

Learn more biomedcentral.com/submissions 